внесеними згідно із Законами N 601-VI ( $601-17$ ) від 25.09.2008, BBP, 2009, N 13, ст.155, N 663-VII ( 663-18 ) від 24.10.2013, ВВР, 2014, N 22, ст.781, N 1193-VII ( $1193-18$ ) від 09.04.2014, BBP, 2014, N 23, ст.873.

$$
2 .
$$

енергозабезпечення. Фокус на будівлі. [Електронний ресурс] Держенергоефективності України. - 2014. - Режим доступу:

Http://saee.gov.ua/uk/consumers/derzhpidtrymka-energozabespechenya/focus-na-budivli

3. Відновлювана енергетика. Сучасний стан [Електронний ресурс] Держенергоефективності України. - 2014. - Режим доступу:

http://saee.gov.ua/uk/activity/vidnovlyuvanaenerhetyka/suchasny-stan

4. Бондаренко В.I. Энергетика: история, настоящее и будущее. От огня и воды к электричеству / Бондаренко В.І., Варламов Г. Б., Вольчин І.А. Монографія- К., 2011. - 264 с.

5. Гайдаєнко I. Альтернативна енергетика в Україні: стан та перспективи розвитку/ Гайдаєнко I. // Наукові записки 3 української історії: Зб. наук. статей, 2014. - Вип. 34. - С. 146151.

6. Калетнік Г.М. Біопалива: ефективність їх виробництва та споживання в АПК України:
Калетнік Г.М., Пришляк В. М.; навч. посібник. К:Аграрна наука, 2010. - 327 с.

7. Ратушняк Г.С. Енергозбереження в сільсько-господарській біоконверсії / Ратушняк Г.С., Джеджула В.В.; навч. посібник. - Вінниця. ВНТУ, 2006. - $83 \mathrm{c}$.

8. Святненко А. «Отримати свою частину зеленого пирога» / Святненко А., Власов В.С.// Дзеркало тижня. - 2010. - № 47

9. Дослідження на основі опитування учасників галузевого ринку [Електронний ресурс] - KPMG - Січень 2013. - Режим доступу: http://www.kpmg.com/UA/uk/IssuesAndInsights/Artic lesPublications/Documents/KPMG_Energy_Survey_1 1012013.pdf

10. Кравченко Е. Альтернативная энергетика 2013. Нормативно-правовое регулирование [Електронний ресурс] - по материалам издания «Юридическая газета» / Е. Кравченко - 2013. - № 42. - Режим доступа: http:/gc.ua/business-news/6672/

11. Васюкова Г.Т Екологія Підручн [Електронний pecypc] http://libfree.com/175948304ekologiyaekologiya_vasyukova_gt.html

12. Тунік Є., Філатова А. Від гною i ліхтарі горять [Електронний ресурс] - Є.Тунік, А.Філатова - 2011. - Режим доступу: http://www.produced.in.ua/techno/45-vd-gnoyu-lhtargoryat.html

Рецензент д.е.н., професор НТУ «ХПI» Архієрєєв С.I. Експерт редакційної колегї к.е.н., доцент УкрДУЗТ єлагін Ю.В.

УДК 316.3 : 33 (477)

\title{
РОЛЬ СУСПІЛЬСТВА В ПРОЦЕСАХ СОЦІАЛЬНО-ЕКОНОМІЧНОЇ ТРАНСФОРМАЦІЇ УКРӒ̈НИ
}

\author{
Дикань В.В, д.е.н., доцент (УкрДУЗТ)
}

У даній статті автором обтрунтовано роль суспільства в процесах соціально-економічної трансформації України. Досліджено еволюиію поглядів на тлумачення сутності суспільства та економіки. Проаналізовано концепцію «людина - економіка», та визначено ї̈ основні положення. Запропоновано основні положення економіки для покращення рівня життя суспільства.

Ключові слова: людина, суспільство, економіка, культура, трансформація Украӥни.

\section{РОЛЬ ОБЩЕСТВА В ПРОЦЕССЕ СОЦИАЛЬНО-ЕКОНОМИЧЕСКОЙ ТРАНСФОРМАЦИИ УКРАИНЫ}

\author{
Дикань В.В., д.е.н., доцент (УкрГУЖТ)
}

В данной статье автором обоснована роль общества в процессах социально-экономической трансформащии Украины. Исследована эволющчия взглядов на толкование сущчности общества и

(C) Дикань B.B.

Вісник економіки транспорту і промисловості № 50, 2015 
экономики. Проанализирована концепция «человек - экономика», и определены ее основные положения. Дополнено теоретические аспекты экономики для улучшения уровня жизни общества.

Ключевые слова: человек, общество, экономика, культура, трансформация Украины.

\section{THE ROLE OF SOCIETY IN SOCIAL AND ECONOMIC TRANSFORMATIONS OF UKRAINE}

\section{Dykan V.V., Ph.D., associate professor (USU of RT)}

In this article the author substantiates the role of society in the process of socio-economic transformation of Ukraine. The evolution of views on the interpretation of the essence of society and the economy. Analyzed the concept of "people - the economy," and defined its basic position. The basic position of the economy to improve living standards suspilstva.Pokazano that at present there need radical revision of indicators reflecting the efficiency of the national economy. Obviously, the only traditional macroeconomic indicators (GDP, inflation and unemployment, etc.) do not reflect the real welfare of the population. They should be complementary indicators that reflect social and cultural settings of the population. Culture and the economy are inextricably linked. Culture must represent a field deployment of all business processes and phenomena connected with human actions.

Keywords: man, society, economy, culture, transformation of Ukraine.

Постановка проблеми. На сьогоднішній день економіка України знаходиться в стані системної кризи, що охопила всі сфери діяльності суспільства. У більшості сегментів економіки йде спад виробництва, дуже низьким залишається рівень та якість життя більшої частки населення. Всі ці зміни породжують необхідність виникнення нових підходів і методів до осмислення сфери людського буття. Саме в умовах наростаючих криз - екологічної, ресурсної, а також кризи самої економічної науки, серцевиною якої виступає неоліберальна теорія, на перший план виходить питання про виживання людства, та стає вкрай необхідним враховувати соціокультурну складову і iii вплив як на окрему людину, так і на економіку в цілому.

Аналіз останніх джерел та пубклікацій. Проблема взаємодії двох ключових сфер життя людського суспільства - економіки і культури, цікавить вчених досить давно. Перші комплексні дослідження в цій області були здійснені в роботах К. Маркса і Ф. Енгельса, а також М. Вебера. Сьогодні ціла плеяда економістів зі світовим ім'ям активно розвиває даний теоретичний напрям сучасної науки. Тут можна згадати, насамперед, роботи таких зарубіжних і вітчизняних вчених як Л. Абалкін, О. Богомолов, Г. Клейнер, Д. Стігліц, А. Некіпелов, Д. Норт, Дж. Ходжсон, та ін. [1-7] Узагальнюючи теоретичні положення, зроблені в численних публікаціях цих дослідників, можна зробити висновок, що у працях цих науковців недостатньо повно висвітлено роль суспільства в процесі соціально-економічної трансформації України. Це і обумовило вибір мети статті.

Мета статті. Дослідження ролі

суспільства в процесі соціально-економічної трансформації України.
Виклад основного матеріалу. Зміна соціально-економічної ситуації на рубежі XX XXI століть зачіпає багато країн світу, в тому числі відбувається глибока трансформація суспільного устрою України. Соціально-економічні зрушення зачепили всі сфери суспільного життя: умови економічної діяльності, механізм управління, рівень розвитку економіки, політичну сферу.

У зв'язку з цим особливої актуальності набувають питання, пов'язані 3 визначенням ролі суспільства в процесі соціально-економічної трансформації України. В рамках економічних процесів сучасності економічна культура стає потужним інститутом зміни суспільства, що забезпечує його високу мобільність.

3 давніх часів людина та економіка нерозривно пов'язані один 3 одним. Економічне життя, відчуваючи на собі вплив всіх сторін суспільного життя (соціальної, політичної, духовної), істотно впливає на різні явища суспільного життя і людства в цілому.

Людина $є$ вихідною клітинкою (ядром) системи соціально-економічних відносин в громадському секторі. Вона виступає суб'єктом, метою і засобом розвитку економіки.

Людина, як суб'єкт економіки формується i розвивається в системі ринкових відносин (розподіл праці, товарний обмін, прибуток, конкуренція, монополія та ін.). Ринкові відносини обумовлюють необхідність ії функціонування в якості людського капіталу. Людина виступає як інвестор і як споживач.

Економіка - це господарська система, що забезпечує задоволення потреб людей і суспільства шляхом створення і використання необхідних життєвих благ. [1, с. 19-20]. Ї̈ головна мета підтримка життєдіяльності людей, створення умов для продовження людського роду. Виробництво, 
розподіл, обмін і споживання товарів і послуг основні характеристики економічного життя суспільства.

Якщо до розпаду СРСР, в нашій державі головною ідеологією був марксизм, своєрідно розвинений спочатку Леніним, потім Сталіним i вважалося, що все економічне життя в країні має регулювати держава, людина розглядається як колективна істота - «соціальна людина», та будьякі ऑii індивідуальні потреби знаходилися на другому плані, все в суспільстві повинно було плануватися державою, інтереси індивідуума підпорядковувалися інтересам колективу, то після розпаду СРСР все в край змінилося: держава не повинна нічого регулювати, ринок сам все налагодить, ніякі потреби соціуму не важливі тільки потреби особистості. Людина стала розумітися як істота, всі дії якої визначаються вигодою. Саме ця ідеологія поки реально домінує в нашій країні.

3 цього приводу, китайський академік Лі Цзин Цзе сказав: в запозиченні досягнень західної культури небезпечно допускати як ухили вліво, так i ухили вправо. Ухилом вліво він називає курс Радянського Союзу при соціалізмі, ухилом вправо - курс України в пострадянський період. I те й інше приносить негативні результати. Валовий національний продукт Китаю під час мирової кризи в минулому зріс, а наш - впав і продовжує скорочуватися.

Так, А.Д. Некіпелов, вважає, що сучасна економічна наука, сформована на базі концепції «людина-економіка» i $є$ великим досягненням, оскільки має солідний теоретичний апарат. Але 3 іншого боку, вона має серйозні обмеження i недоліки, оскільки «людина-економіка» - це абстракція. А. Д. Некіпелов звертає увагу, що дана концепція припускає наявність у господарюючого суб'єкта певної ціннісної установки. Саме прагнення до вигоди - це різновид ціннісної орієнтації. Виявляється, що в такій якості культурна складова інтегрована в саме серце економічної теорії [2]. 3 цього випливає, що не слід відкидати досягнення ліберального економічного «мейнстріму», оскільки існує можливість впровадити в серцевину цієї теорії інше розуміння людини. Видається, що це - виключно перспективна ідея, що відкриває захоплюючі можливості для теоретичного прориву шляхом інтеграції економіки та культури.

Проаналізувавши концепцію «людина економіка», автор визначає наступні положення:

- існування суспільства неможливе без постійного виробництва матеріальних благ;

- суспільне виробництво визначає появу і розвиток соціальної структури;

- економічні відносини активно впливають на політичне життя суспільства (економічно панівні соціальні групи, як правило, прагнуть впливати на роботу держапарату, напрямки діяльності політичних партій та ін.);

-в процесі виробництва створюються необхідні матеріальні умови для розвитку духовного життя суспільства (будівлі бібліотек, театрів, обладнання для видання книг, газет і т. п.). Вочевидь, що зміна в одній сфері спричинить за собою зміну в інший, а це означає, що повноцінне існування однієї сфери без іншого неможливо.

Дуже цікавою є думка академіка О.Т. Богомолова, він вважає, що сучасна економіка потребує демократичної перебудови. Вона потребує вільних, освічених i незалежних спеціалістів. Глобалізація стимулює поширення демократії, оскільки інформація і знання дуже швидко стають загальносвітовим надбанням. Приклади успішно функціонуючої демократії знаходять велику притягальну силу для прогресивної громадськості і навіть правлячих кіл у різних країнах світу. Все більше накопичується доводів і фактів на користь того, що ефективна демократія, яка втілює в життя свої основоположні принципи, може бути серйозним фактором економічного зростання та підвищення національної конкурентоспроможності [ 3, с. 297298].

Однак при низькому матеріальному i культурному рівні населення, при спадщині вікової несвободи спроби прискореного переходу до демократичного устрою західноєвропейського або американського типу можуть принести протилежні результати. Неосвіченими і забитими життєвими тяготами людьми маніпулювати легко. У таких умовах свобода і гласність можуть обернутися урочистістю безправ'я і демагогії, розгулом криміналу i самоуправства. Вони здатні розчистити шлях наверх для кар'єристів i пройдисвітів. Тому утвердження демократії в незрілому суспільстві має бути поетапним і досить тривалим процесом. В ім'я підтримки стабільності і порядку в суспільстві, в інтересах підготовки та поступового дозрівання справжньої демократії свобода волевиявлення та вибору, гласність і свобода слова можуть піддаватися контролю i обмеженню з боку пануючих верхів. Але це може робитися верхами i 3 корисливою метою максимально довгого утримання влади відходу від відповідальності за зловживання нею.

Також, автор пропонує зробити акцент на значенні освіти в формуванні розвитку суспільства та держави в цілому. На сьогодні недостатньо уваги приділяється якості освіти. Багато людей прагнуть отримати освіту, але у них недостатньо коштів, а ті хто отримують іiі, потім не можуть гідно працевлаштуватися, через недостатність робочих місць.

У США антикризові програми будують таким чином, щоб рішення сьогоднішніх проблем поєднувалося 3 отриманням великих ефектів в 
майбутньому. "Ми дамо людям роботу на будівництві шкіл, лабораторій, бібліотек, - говорив Президент США Б.Обама, - щоб наші діти могли конкурувати з будь-якими працівниками у світі". "Сьогодні наука більше, ніж будь-коли раніше, потрібна для нашого добробуту, нашої безпеки, нашого здоров'я, збереження нашого довкілля i нашої якості життя", - це теж слова Б. Обами.

Узагальнюючи думки науковців, можна відзначити загальні риси існуючих економічних положень, які спрямовані на розвиток рівня життя суспільства:

1. Економічне зростання. Зростання економіки, що забезпечує людський розвиток, матеріальне благополуччя.

2. Повна зайнятість. Утримання безробіття на природньому рівні.

3. Стабільність цін. Забезпечення фінансової стабільності, протидія інфляції.

4. Забезпечення демократичних процедур прийняття найважливіших державних рішень, чесне інформування суспільства про стан справ у країні, підтримка інститутів громадянського суспільства, гарантування незалежності ЗМI i демократичний контроль за їх діяльністю.

5. Економічна безпека. Збереження стійкості до зовнішніх та внутрішніх загроз, здатність національної економіки до розширеного самовідтворення для задоволення потреб громадян, суспільства і держави на якомусь визначеному рівні.

6. Соціальна стабільність. Створити рівні можливості (незалежно від матеріального положення, релігії, національності та місця проживання) для реалізації своїх здібностей i забезпечення власною працею гідного рівня життя; недопущення безпрецедентної прірви між бідними та багатими, масової бідності та високого рівня безробіття, забезпечення гідного рівня середньої заробітної плати.

7. Справедливе оподаткування. Співвідношення ставки оподаткування та рівня доходів громадян.

8. Активізація ролі держави в дотриманні інтересів усього суспільства, у формуванні соціально справедливої політики доходів, у наданні основних соціальних гарантій всьому населенню, у розвитку науки, культури, охорони здоров'я і освіти, в охороні навколишнього природного середовища, у підтримці інновації та технічного прогресу, в боротьбі із злочинністю і в підтримці необхідного морального клімату в країні.

9. Забезпечити високу якість, та доступність освіти, що сприятиме формуванню кваліфікованих кадрів та рівню освіченості української нації.

Так, враховуючи всі ці положення, можна сказати, що для поліпшення рівня життя суспільства необхідними $є$ впевненість у завтрашньому дні, наявність політичних свобод i соціальних гарантій, свобода вибору, рівень освіти, можливість довіри оточуючим людям. У кожній країні свобода вибору, рівень достатку, соціальна захищеність оцінюються з урахуванням унікальних особливостей культури та історії.

$$
\text { Сьогодні потрібно }
$$

переглянути показники, шо ефективність функціонування національної економіки. Очевидно, що тільки традиційні макроекономічні показники (розмір ВВП, рівень інфляції та безробіття і т.п.) не відображають реального рівня добробуту населення країни. Їх необхідно доповнювати показниками, що відображають соціокультурні погляди населення країни. Культура i господарство нерозривно пов'язані між собою. Культуру необхідно представляти як поле розгортання всіх господарських процесів і явищ, пов'язаних саме 3 діями людини. «Не будемо забувати, що культура включає в себе не тільки одні культи, храми, книги, твори мистецтва, знаряддя праці, а й звичаї, норми, встанови, цінності, ідеології манери поведінки, а також саме суспільний устрій, державний порядок »[4].

Висновок. Саме в умовах кризи економічної науки, серцевиною якої виступає неоліберальна теорія, на перший план виходить питання про виживання людства, та стає вкрай необхідним враховувати соціокультурну складову і iii вплив як на окрему людину, так і на економіку в цілому.

Подальше дослідження має бути спрямоване на визначення концептуальних основ розвитку суспільства в умовах інноваційної економіки.

\section{СПИСОК ЛІТЕРАТУРИ}

1.История мировой экономики: учебник вузов/ Под ред. Г. Б. Поляка. А. Н. Марковой. М.: ЮНИТИ., 2002.-727 с.

2. Некипелов А. Д. Экономика и культурные ценности /А.Д. Некипелов // Диалог культур и партнерство цивилизаций : IX Междунар. Лихачевские науч. чтения, 14-15 мая 2009 г. СПб. : СПбГУП, 2009. - С. 101.

3. Богомолов О.Т. Не экономические грани экономики: неопознанное взаимовлияние. Научные и публицистические заметки обществоведов / О.Т. Богомолов, Б.Н. Кузик // М.: Институт экономических стратегий, 2010. - 800с.

4. Задорожная О.Г. Человек в современном общественном производстве. Социокультурные факторы хозяйства / О.Г. Задорожная //Социальная экономика. .- 2006. - №3-4- С.17-25. 
5. Бенин В. Л. Учебное пособие по теории и практики управления. - 2007. - № 5. - С. 30социальной философии. / В. Л.Бенин, М. В. 42. Десяткина. - Уфа: БГПУ, 1997. - 86 с.

6. Клейнер, Г. Системный подход к экономической политике / Г. Клейнер // Проблемы

7. Ходжсон Дж. Социально-экономические последствия прогресса знаний и нарастания сложности / Дж.Ходжсон // Вопросы экономики. 2001.- №8.

Експерт редакційної колегії к.е.н., доцент УкрДУЗТ Токмакова І.В.

УДК $658.7: 656.2$

\title{
ФОРМУВАННЯ СТРУКТУРИ ТРАНСПОРТНО-ЛОГІСТИЧОГО КЛАСТЕРА У ТРАНСКОРДОННОМУ СПІВРОБІТНИЦТВІ
}

\author{
Озерська Г.В., к.е.н., доцент (ХНУРЕ)
}

У статті запропоновано структуру транспортно-логістичного кластеру у транскордонному співробітництві у контексті регіонального розвитку. Автором визначено, щзо регіональний транспортнологістичний кластер у транскордонному співробітництві матиме дворівневу структура. Зокрема, перший рівень - внутрішній - запропоновано будувати за рахунок споживчого ринку регіону, а саме підприємств промисловості, транспорту, торгівлі тощо, організащій та населення регіону, а також елементів $і$ ланок транспортно-логістичного кластеру. Другий рівень - зовнішній - формується за рахунок аналогічних об’єктів різних регіонів України, країн СНД і далекого зарубіжжя. Автором зазначено, щзо в умовах реалізації транскордонного співробітництва створення цे інтеграція регіональних транспортнологістичних кластерів є одним з першочергових інструментів реалізачії державної регіональної політики, щзо спрямована на підвищення рівня життя громадян прикордонних територій, забезпечення конкурентоспроможності господарського комплексу, впровадження інноваційно-інвестиційної моделі розвитку, гармонізацію нормативно-правових і сочіально-економічних умов розвитку промислового та сільськогосподарського виробництв, кооперачії, науково-технічного й інших видів прикордонної взаємодї, особливо у сфері бізнесу, надання послуг і трансферту технологій.

Ключові слова: транспортно-логістичний кластер, регіональний розвиток, транскордонне співробітництво, структура транспортно-логістичного кластеру, рівні структури транспортнологістичного кластеру.

\section{ФОРМИРОВАНИЕ СТРУКТУРЫ ТРАНСПОРТНО-ЛОГІСТИЧОГО КЛАСТЕРА В ТРАНСГРАНИЧНОМ СОТРУДНИЧЕСТВЕ}

\author{
Озерская А.В., к.э.н., доцент (ХНУРЭ)
}

В статье предложена структура транспортно-логистического кластера в трансграничном сотрудничестве в контексте регионального развития. Автором определено, что региональный транспортно-логистический кластер в трансграничном сотрудничестве будет иметь двухуровневую структуру. В частности, первый уровень - внутренний - предложено строить за счет потребительского рынка региона, а именно предприятий промышленности, транспорта, торговли, организаций и населения региона, а также элементов и звеньев транспортно-логистического кластера. Второй уровень внешний- формируется за счет аналогичных объектов различных регионов Украины, стран СНГ и дальнего зарубежья. Автором отмечено, что в условиях реализации трансграничного сотрудничества создание и интеграция региональных транспортно-логистических кластеров является одним из первоочередных инструментов реализаџии государственной региональной политики, направленной на повышение уровня жизни граждан приграничных территорий, обеспечение конкурентоспособности хозяйственного комплекса, внедрение инновационно-инвестиционной модели развития, гармонизацию нормативно-правовых и соџиально-экономических условий развития промышленного $и$ сельскохозяйственного производств, кооперации, научно-технического и других видов приграничного взаимодействия, особенно в сфере бизнеса, предоставления услуг и трансферта технологий.

Ключевые слова: транспортно-логистический кластер, региональное развитие, 